\title{
Opportunistic citizen science data could be a faster and more efficient way to detect and monitor the spread of invasive species especially in developing countries: The case of harlequin ladybird Harmonia axyridis in Algeria.
}

sadek atoussi ( $\square$ atoussi.sadek@univ-guelma.dz)

Universite 8 Mai 1945 Guelma https://orcid.org/0000-0001-8303-6313

Imane Razkallah

Université Badji Mokhtar Annaba: Universite Badji Mokhtar Annaba

Rabah Zebsa

Universite 8 Mai 1945 Guelma

Zinette Bensakhri

Centre Universitaire Abdelhafid Boussouf Mila

Mouslim Bara

Universite 8 Mai 1945 Guelma

\section{Research Article}

Keywords: Citizen Science, Harlequin ladybird, invasion, Algeria

Posted Date: March 1st, 2021

DOI: https://doi.org/10.21203/rs.3.rs-214552/v1

License: (c) (i) This work is licensed under a Creative Commons Attribution 4.0 International License.

Read Full License 


\section{Abstract}

Accelerated spread of the non-native species Harmonia axyridis in Algeria may pose problem to local biodiversity, and new challenges to natural resource management, and economies. Three new records of this species have been detected in different part of the country via an investigation on social media platforms and, in a citizen science database. Our findings indicate the presence of the species in at least three localities, more than $400 \mathrm{~km}$ away for the most distant of them, and highlighted the important role of citizen science in developing countries where the funding of doing research in that field almost nonexistent.

\section{Introduction}

Scientific research is a time-consuming activity that requires a significant mobilization of human and material resources that are sometimes very expensive. This question is particularly relevant in developing countries, where lack of funding opportunities is an issue of concern for scientific research development (World Bank 2005).

Citizen science is a new fast-growing source of data that has the potential to add to our scientific knowledge of natural resources and biodiversity trends (Pocock et al. 2019). Scientists, governmental agencies, and NGOs would have a clear benefit in using citizen science to meet the collective obligations toward biodiversity conservation, and United Nations' Sustainable Development Goals (Chandler et al. 2017, Pocock et al. 2019). A study performed in the UK indicates that by using direct or verified citizen science, a program can collect 3-4 times the number of samples provided by traditional research for the same cost making citizen science programmes a good alternative for data collection (Gardiner et al. 2012). However, this seems to be a paradox, when we see that the countries with fewer resources and which are nevertheless the most called upon to reflect on the different means of developing research at lower costs, are those which make the least use of citizen science programmes (Loos et al. 2015; Chandler et al. 2017; Pocock et al. 2019).

The harlequin ladybird Harmonia axyridis (Pallas 1773) (Coleoptera, Coccinellidae) is an alien invasive species native to Asia and is the most invasive ladybird on Earth (Roy et al. 2006). The species was introduced accidentally or as a control agent in many countries, where it quickly came into competition with local biodiversity, with all the negative consequences of such interactions (Grez et al. 2016). In Africa, the first record of the species in the wild was in South Africa in 2001, Egypt in 2007, and Kenya in 2010 (Brown et al. 2011). The predicted global distribution of "Harmonia axiridis" according to Brown et al. 2011 indicates that large areas of southern and eastern Africa and the coastal belt of northern Africa are suitable for the species.

During an excursion with children organised in April 2020 by a local NGO to observe insects in the region of Guelma "north-eastern Algeria", we identified three species of ladybirds, including the Asian ladybird "Harmonia axyridis", whose presence was first reported in Algeria in 2018 (Lakhal et al. 2018). 
We then aimed to test the effectiveness of opportunistic data from citizen science; to detect and monitor the spread of the invasive harlequin ladybird in an African context. We carried out research on two Facebook interest groups dedicated to wildlife observation, and on iNaturalist. To see if citizens in Algeria: (1) Observed "Harmonia axyridis" ladybird and shared their observations on social media interest groups? (2) Correctly identified the species? (3) Reported data on the location of these observations, which could help to monitor the spread of the species?

\section{Searching In Citizen Science Database/ Methods}

We searched in two Facebook interest groups dedicated to wildlife observation, using keywords ladybird in French, English and Arabic (Fig. 1). The first group "to save wildlife in Algeria" is a group created on 17 July 2013 by the Algerian wildlife association and which gathers 21500 members.

The second group "Le monde de la vie sauvage en Algérie" created on 9 January 2018 is a public group with more than 13000 members.

We downloaded all the photos of ladybirds posted by the members of these groups, which we then identified with a specialist. Information on the dates and places where the photos showing the species "Harmonia axyridis" were taken was obtained by contacting the photographers by messenger.

The iNaturalist web site (http://www.inaturalist.org), is a multi-taxa opportunistic citizen science project hosted by the California Academy of Sciences and National Geographic Society. Participants contribute observations (e.g., photos, recordings) of any living organism with location and date assigned. Records

are then tagged and identified to the lowest possible taxonomic resolution by other iNaturalist community members. We made a search using the word ladybird, in French, Arabic and English and selecting the region Algeria. The photos of the observations provided by this research were subsequently identified by a specialist to confirm the taxonomy.

\section{Results And Discussion}

On Facebook, we found three photos of "Harmonia axyridis", posted in the group "Le monde de la vie sauvage en Algérie". Two of them were posted by the same person, with the dates marked on the photos, as far as the place is concerned, the person who took the photos told us that they were taken in the region of Tipaza, at a distance of more than $40 \mathrm{~km}$ from where the species was observed for the first time. The third photo was taken on 13 July 2020 in Algiers. It is also interesting to note that the species was correctly identified in the comments related to the posted photos.

On iNaturalist we found a single photo showing a larva of "Harmonia axyridis" in the region of Skikda, which is about $350 \mathrm{~km}$ from the place of the first known observation of the species. Since its first observation in 2017, personal observations, and opportunistic citizen science data collected on Facebook and iNaturalist platforms, indicate the presence of "Harmonia axyridis" in at least three other localities, more than $400 \mathrm{~km}$ away for the most distant of them (Fig. 2). 
Our record extends the geographic spread of documented Harmonia axyridis across Algeria (Lakhal et al. 2018). This supports the idea that this invasive ladybirds has a potential fast spread across earth via direct and indirect factors toward wet or dry region in the tropic climate (Poutsma 2008; Loy et al. 2016; Nedvěd and Háva 2016; Biranvand et al. 2019)

The results of these studies will be of great interest for the management and conservation of the Algerian insect biota. Showing a very rapid dispersal of this species and its strong invasive potential, and the need to follow its evolution throughout the country. Future projects on assessment of invasion species and their interactions in local to large scale may provide information on the possible impacts of non-native species on the community organization and ecosystem functioning.

\section{Conclusion}

Even if several studies indicate a minor engagement of African countries in citizen science programs such as e-bird. This study shows that opportunistic data collection on social networks could be of great interest, not only that but also that the potential for engaging citizens of African countries in citizen science programs is real if there is good communication around these programs, bringing the right message to the right people and through the right communication medium. Hence, the need for academics in association with IT developers, NGOs, and governmental agencies to organize a biodiversity monitoring framework based on citizen science to meet the collective obligations toward biodiversity conservation and United Nations' Sustainable Development Goals.

\section{Declarations}

\section{Acknowledgements}

Many thanks to the photographers who shared their observations on social media platforms, and on citizen science websites; we also thank anonymous reviewers for their constructive comments.

\section{Data Availability Statement}

The data that support the findings of this study are available from the corresponding author upon reasonable request.

\section{References}

Brown PM, Thomas CE, Lombaert E, Jeffries DL, Estoup A, Handley LJL (2011) The global spread of Harmonia axyridis (Coleoptera: Coccinellidae): distribution, dispersal and routes of invasion. BioControl, 56(4), 623-641.

Biranvand A, Nedvěd O, Tomaszewska W, Al Ansi AN, Fekrat L, Haghghadam ZM, Haelewaters D (2019) The genus Harmonia (Coleoptera, Coccinellidae) in the Middle East region. Acta Entomologica Musei 
Nationalis Pragae, 59 (1), 163-170.

Callaghan CT, Ozeroff I, Hitchcock C, Chandler M (2020) Capitalizing on opportunistic citizen science data to monitor urban biodiversity: A multi-taxa framework. Biological Conservation, 251, 108753.

Grez AA, Zaviezo T, Roy HE, Brown PM, Bizama G (2016) Rapid spread of Harmonia axyridis in Chile and its effects on local coccinellid biodiversity. Diversity and Distributions, 22(9), 982-994.

Hiller T, Haelewaters D (2019) A case of silent invasion: Citizen science confirms the presence of Harmonia axyridis (Coleoptera, Coccinellidae) in Central America. PloS one, 14(7), e0220082.

Chandler M, See L, Copas K, Bonde AM, López BC, Danielsen F, Rosemartin A (2017) Contribution of citizen science towards international biodiversity monitoring. Biological Conservation, 213, 280-294.

Gardiner MM, Allee LL, Brown PM, Losey JE, Roy HE, Smyth RR (2012) Lessons from lady beetles: accuracy of monitoring data from US and UK citizen-science programs. Frontiers in Ecology and the Environment, 10(9), 471-476.

Lakhal MA, Ghezali D, Nedvěd O, Doumandji S (2018) Checklist of ladybirds of Algeria with two new recorded species (Coleoptera, Coccinellidae). ZooKeys, (774), 41.

Loos J, Horcea-Milcu Al, Kirkland P, Hartel T, Osváth-Ferencz M, Fischer J (2015) Challenges for biodiversity monitoring using citizen science in transitioning social-ecological systems. Journal for Nature conservation, 26, 45-48.

Pocock MJ, Roy HE, August T, Kuria A, Barasa F, Bett J, Kissui B (2019) Developing the global potential of citizen science: Assessing opportunities that benefit people, society and the environment in East Africa. Journal of applied ecology, 56(2), 274-281.

Poutsma J, Loomans AJM, Aukema B, Heijerman T (2008) Predicting the potential geographical distribution of the harlequin ladybird, Harmonia axyridis, using the CLIMEX model. BioControl 53: 103125.

Roy HE, Brown P, Majerus MEN (2006) Harmonia axyridis: a successful biocontrol agent or an invasive threat? In: Eilenberg J, Hokkanen $\mathrm{H}$ (eds) An ecological and societal approach to biological control. Kluwer Academic Publishers, Netherlands

Roy HE, Brown PMJ, Adriaens T, Berkvens N, Borges I, Clusella-Trullas S, Comont RF, De Clercq P, Eschen R, Estoup A, Evans EW, Facon B, Gardiner MM, Gil A, Grez AA, Guillemaud T, Haelewaters D, Herz A, Honek A, Howe AG, Hui C, Hutchison WD, Kenis M, Koch RL, Kulfan J, Handley LL, Lombaert E, Loomans A, Losey J, Lukashuk AO, Maes D, Magro A, Murray KM, Martin GS, Martinkova Z, Minnaar IA, Nedvěd O, Orlova-Bienkowskaja MJ, Osawa N, Rabitsch W, Ravn HP, Rondoni G, Rorke SL, Ryndevich SK, Saethre MG, Sloggett JJ, Soares AO, Stals R, Tinsley MC, Vandereycken A (2016) The harlequin ladybird, 
Harmonia axyridis: global perspectives on invasion history and ecology. Biological Invasions 18(4): 9971044.

Nedvěd O, Háva J (2016) New record of the invasive lady beetle Harmonia axyridis in Afrotropical Region: Tanzania, Zanzibar. African Entomology 24: 247-249.

WORLD BANK (2005) Meeting the Challenge of Africa's Development: A World Bank Group Action Plan. World Bank, New York.

https://www.worldbank.org/en/region/afr/publication/improving-the-quality-and-quantity-of-scientificresearch-in-africa (Acceded 18/11/20).

\section{Figures}
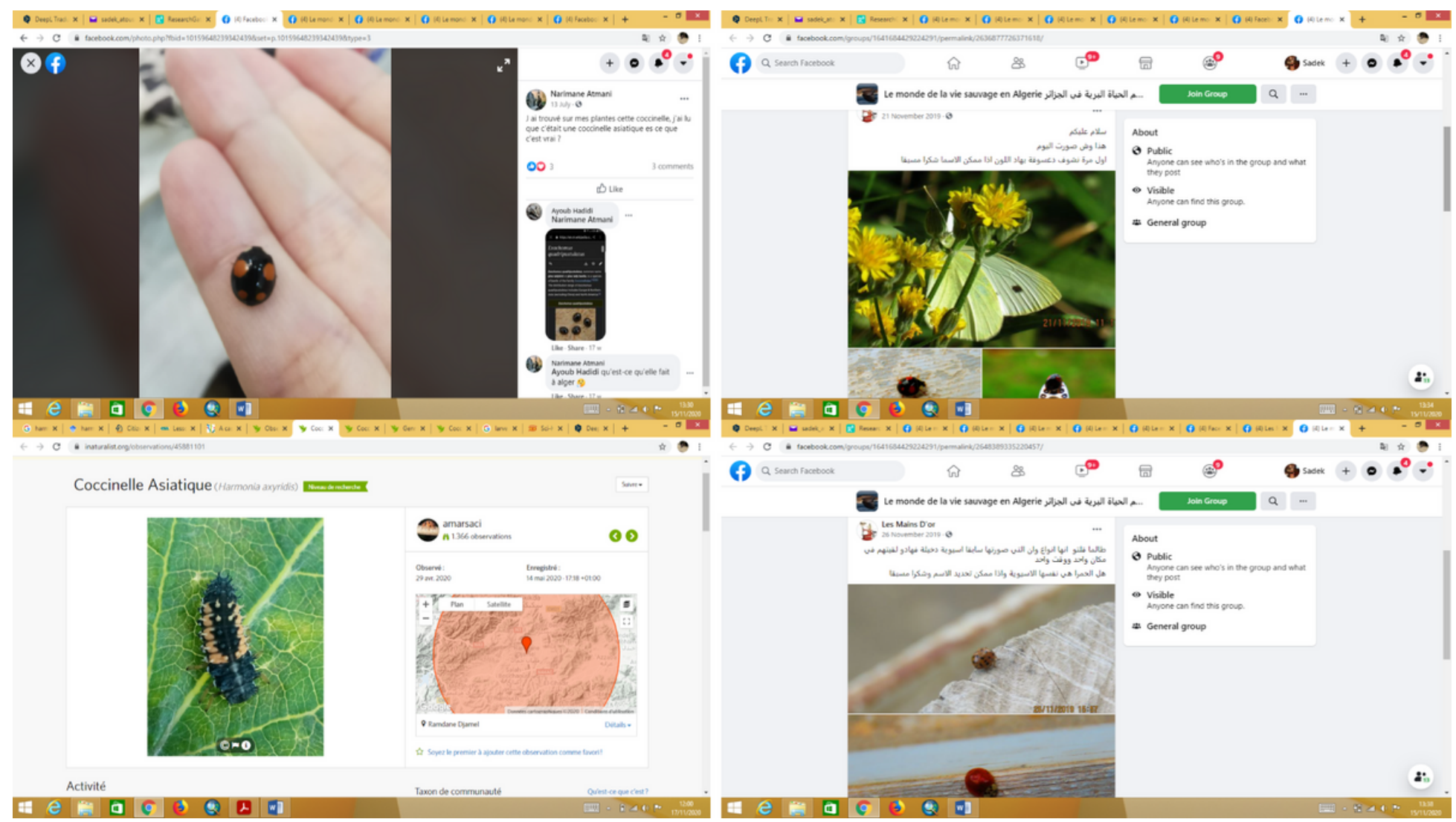

\section{Figure 1}

Research procedures within groups on facebook and iNaturalist website. 


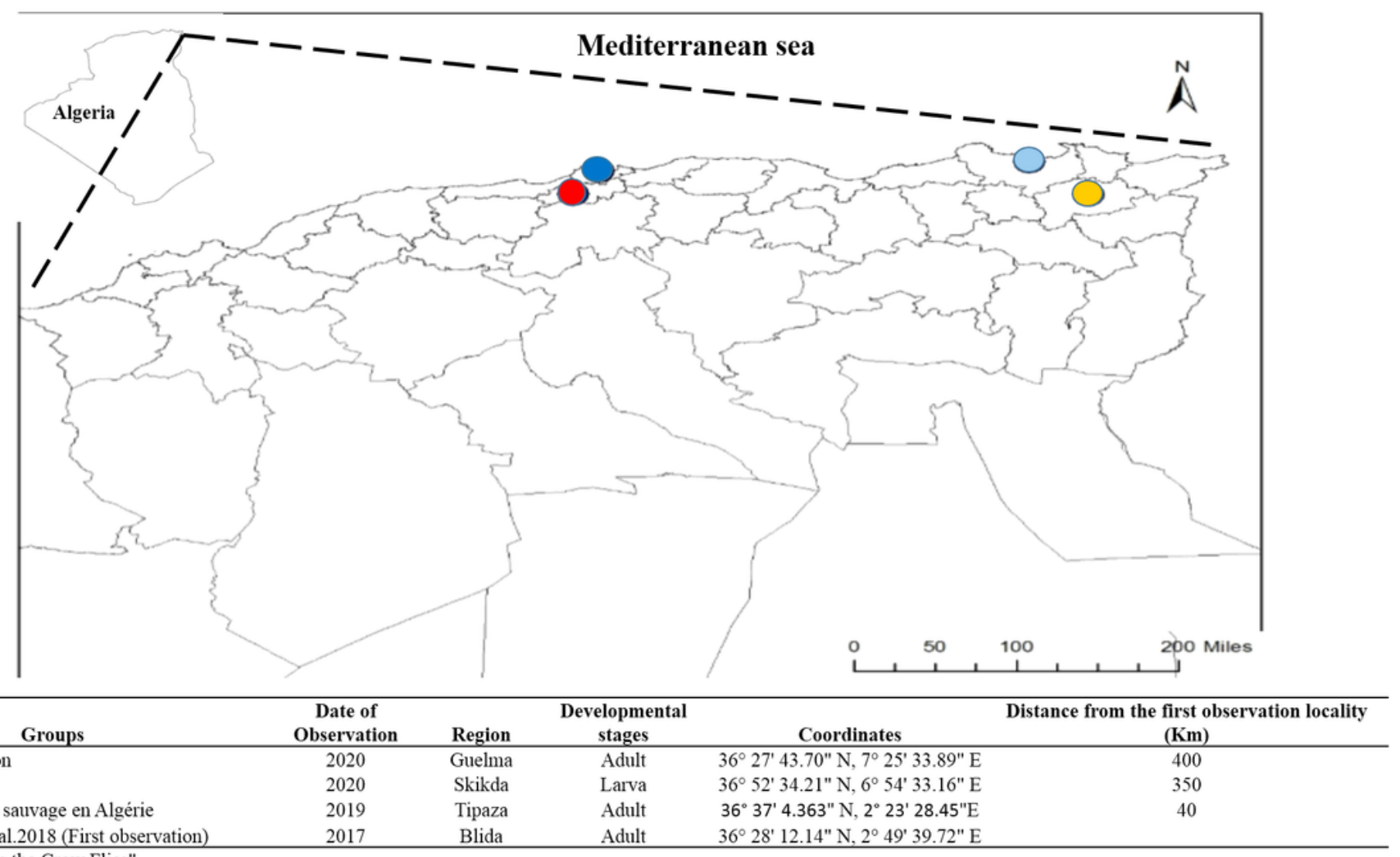

Note: Distances "As the Crow Flies"

\section{Figure 2}

Records of the species of Harmonia axyridis (Pallas, 1773) in Algeria. Developmental stages, region, date of observation, and distance from the first observation are provided. 